\title{
Sigmatropic Rearrangements of 2,4-Dinitrophenyl Oximes
}

\author{
Peter H. Boyle,* Haslin Dato Paduka Ali, and Thomas J. Mc Donald \\ University Chemical Laboratory, Trinity College, University of Dublin, Dublin 2, Ireland \\ E-mail:pboyle@tcd.ie
}

\begin{abstract}
Dedicated to Professor Anthony McKervey on the occasion of his $65^{\text {th }}$ birthday
(received 05 Mar 03; accepted 14 Apr 03; published on the web 18 Apr 03)
\end{abstract}

\begin{abstract}
Reaction of 6-amino-1,3-dimethyluracil (14) with the 2,4-dinitrophenyl oxime (21) of iodoacetone led to initial condensation followed by an unexpected [3,3] sigmatropic rearrangement, followed in turn by ring closure to give 5-(2-hydroxy-3,5-dinitrophenyl)-1,3,6trimethylpyrrolo[2,3-d]pyrimidine-2,4(1H,3H)-dione (22).

6-Methylamino-1,3-dimethyluracil under the same conditions underwent a similar sigmatropic rearrangement, but the product cyclised instead to give 1,3-dimethyl-6-methylamino-5-(2methyl-5,7-dinitro-3-benzo[b]furanyl)pyrimidine-2,4(1H,3H)-dione (32). A third type of product, 4-amino-6-(2-hydroxy-3,5-dinitrophenyl)-5-methyl-2-phenylfuro [2,3-d]pyrimidine (35), was obtained when 6-amino-2-phenyl-4(3H)-pyrimidinone (33) reacted with the 2,4dinitrophenyl oxime (19) of chloroacetone in presence of potassium iodide. Mechanisms are suggested for these unusual reactions.
\end{abstract}

Keywords: 2,4-Dinitrophenyl oximes, 1,3-dimethyluracil, sigmatropic, iodoacetone, chloroacetone, pyrrolo[2,3-d]pyrimidine, benzo[b]furans, furo[2,3-d]pyrimidine

\section{Introduction}

It was shown recently by Narasaka ${ }^{1-4}$ and co-workers that 2,4-dinitrophenyl oximes can serve as a source of electrophilic nitrogen, and that in suitable cases intramolecular electrophilic cyclisation of nitrogen on to a benzene ring may lead ultimately to the formation of quinolines. It was shown, ${ }^{1}$ for example, that 2-methyl-8-hydroxyquinoline (2) could be obtained from the 2,4dinitrophenyl oxime (1). It was therefore of interest to see if 2,4-dinitrophenyl oximes such as (3) or (4) could undergo intramolecular cyclisation on to the pyrimidine 5-position to give 7,8dihydropteridines (5) or (6) respectively, which could be readily oxidised to the corresponding fully aromatic pteridines. No pteridine has yet been synthesised by a route of this type. 


\section{Results and Discussion}

Various approaches to the synthesis of oximes (3) and (4) were explored, but they all encountered problems. For example, the diethyl acetal (8) could be prepared readily by reaction of 6-chloro-1,3-dimethyluracil ${ }^{5}$ (7) with the diethyl acetal of aminoacetaldehyde. ${ }^{6}$ Hydrolysis of (8) with $\mathrm{HCl}$, however, afforded none of the required aldehyde (9), and led only to the pyrrolo[2,3-d] pyrimidine ${ }^{7}$ (10), formed in situ by cyclisation of the aldehyde (9). Milder methods of acetal hydrolysis based on silica failed to hydrolyse the acetal group in (8). ${ }^{8}$<smiles>C/C(CCc1cccc(O)c1)=N/Oc1ccc([N+](=O)[O-])cc1[N+](=O)[O-]</smiles>

(1)

(2)<smiles>[R]C1=NC([R])=Nc2c(n(C)c(=O)n(C)c2=O)NC1</smiles>

(3) $\mathrm{R}=\mathrm{H}$

(4) $\mathrm{R}=\mathrm{CH}_{3}$

(5) $\mathrm{R}=\mathrm{H}$

(6) $\mathrm{R}=\mathrm{CH}_{3}$

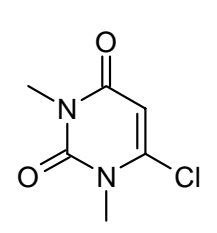

(7)<smiles>CCOC(CN)OCC</smiles>

(8)<smiles>CCCNc1cc(=O)n(C)c(=O)n1C</smiles>

(9)<smiles>Cn1c(=O)c2cc[nH]c2n(C)c1=O</smiles>

(10)

It was also found impractical to use the methyl ketone (12) as a precursor for oxime (4). Although (12) was prepared as described below it was found to cyclise extremely readily to the pyrrolo[2,3-d]pyrimidine (13), and could be obtained only in small amounts. It was prepared from alcohol (11), which could be obtained in good yield by refluxing 6-chloro-1,3dimethyluracil (7) in aqueous solution with 1-amino-2-propanol. Oxidation of (11) using a variety of methods, including the Swern oxidation, always led to the cyclised material (13) as the main product, however, formed by in situ cyclisation of the initially formed ketone (12). A small amount of (12) could be isolated by chromatography, but a solution of it in ethanol was converted very rapidly into (13) when stirred with silica. Reaction of (7) with 2-amino-1phenylethanol gave the phenyl analogue of alcohol (11), namely 6-(2-hydroxy-2phenylethylamino)-1,3-dimethyluracil. Attempts to oxidise the latter to the corresponding ketone were also unsuccessful, however. 
<smiles>Cn1c(Cl)cc(=O)n(C)c1=O</smiles>

(7)

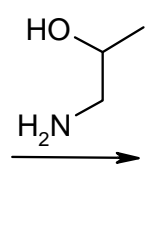

(11)<smiles>CC(O)CNc1cc(=O)n(C)c(=O)n1C</smiles><smiles>CC(=O)CNc1cc(=O)n(C)c(=O)n1C</smiles>

(12)
(13)

Another approach towards the preparation of methyl ketone (12) involved the treatment of 6amino-1,3-dimethyluracil (14) with iodoacetone. No reaction occurred on refluxing these reagents together in water solution. Reaction in methanol in a pressure tube at $120{ }^{\circ} \mathrm{C}$ did afford two products, however. The first of these proved to be 6-methoxy-1,3-dimethyluracil (15), formed by reaction of (14) with the solvent. It was shown to be identical with an authentic sample of the same material prepared by treatment of 6-chloro-1,3-dimethyluracil (7) with methanolic sodium methoxide. The second product was shown to be 1,3,5-trimethylpyrrolo[2,3d]pyrimidine-2,4(1H,3H)-dione (13). For example, it gave a single HPLC peak, homogeneous by UV, when it was mixed with authentic (13), prepared as described earlier by the oxidation of (11). Its ${ }^{1} \mathrm{H}$ and ${ }^{13} \mathrm{C}$ NMR spectra were also identical with those of authentic (13), and with those reported by Kawahara et al. for the same compound. ${ }^{9}$ These observations confirm that the product obtained was (13) and not its regioisomer ${ }^{10}$ (16), which might have been formed in this reaction.

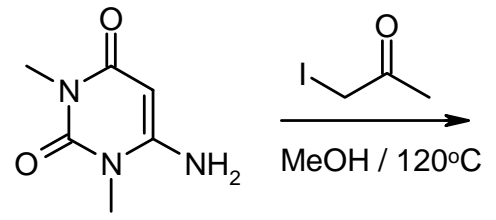

(14)<smiles>COc1cc(=O)n(C)c(=O)n1C</smiles>

(15)<smiles>Cc1c[nH]c2c1c(=O)n(C)c(=O)n2C</smiles>

(13)<smiles>Cc1cc2c(=O)n(C)c(=O)n(C)c2[nH]1</smiles>

(16)

The next experiment involved a reaction between 6-amino-1,3-dimethyluracil (14) and the 2,4-dinitrophenyl oxime (21) of iodoacetone. This was carried out with a view to obtaining oxime (4), and to investigating the possible cyclisation of it to the dihydropteridine (6). Quite unexpectedly, however, the product actually isolated was shown to have structure (22), and in order for this to be formed an unusual sigmatropic rearrangement must have taken place. The 2,4-dinitrophenyl oxime (21) of iodoacetone required for this reaction could be prepared by reaction of O-(2,4-dinitrophenyl)hydroxylamine (18) with iodoacetone, the latter being obtained by a Finkelstein reaction on chloroacetone. ${ }^{11}$ Since iodoacetone is a dangerously lachrymatory compound its preparation by this route is not to be recommended except under very carefully controlled conditions. Iodooxime (21) is also highly lachrymatory, and was used as a crude solid without being completely characterised. Iodooxime (21) could also be prepared from the corresponding chloro compound (19) by reaction of the latter with sodium iodide in dimethylformamide. The chloroacetone 2,4-dinitrophenyl oxime (19) was prepared by reaction 
of O-(2,4-dinitrophenyl)hydroxylamine (18) with chloroacetone. Compound (18) has been prepared by treatment of ethyl O-(2,4-dinitrophenyl)acetohydroxamate (17) with perchloric acid, $^{12}$ and also by treatment of tert-butyl $\mathrm{N}$-(2,4-dinitrophenoxy)carbamate (20) with trifluoroacetic acid. ${ }^{13}$ In our hands the preparation of (18) from (17) was the preferred route, using a modification of the reaction conditions described by Tamura. ${ }^{12}$ Compound (18) is heat labile, and decomposes to 2,4-dinitrophenol on standing at room temperature. It was therefore stored at $4{ }^{\circ} \mathrm{C}$ and used as quickly as possible after preparation. When the 2,4dinitrophenyloxime (19) of chloroacetone was treated with 6-amino-1,3-dimethyluracil (14) under a variety of conditions, including reaction at $120{ }^{\circ} \mathrm{C}$ in a pressure tube, the only product isolated was 2,4-dinitrophenol, formed by thermal decomposition of (19). However, if a one molar amount of sodium or potassium iodide was added to the reaction mixture at $120{ }^{\circ} \mathrm{C}$, reaction did occur to give the new product (22). As already mentioned, the same product was obtained by reaction of the iodooxime (21) with 6-amino-1,3-dimethyluracil (14) in methanolic solution at $120^{\circ} \mathrm{C}$ in a pressure tube. Presumably the chloro compound (19) reacts via its more reactive iodo analogue (21).

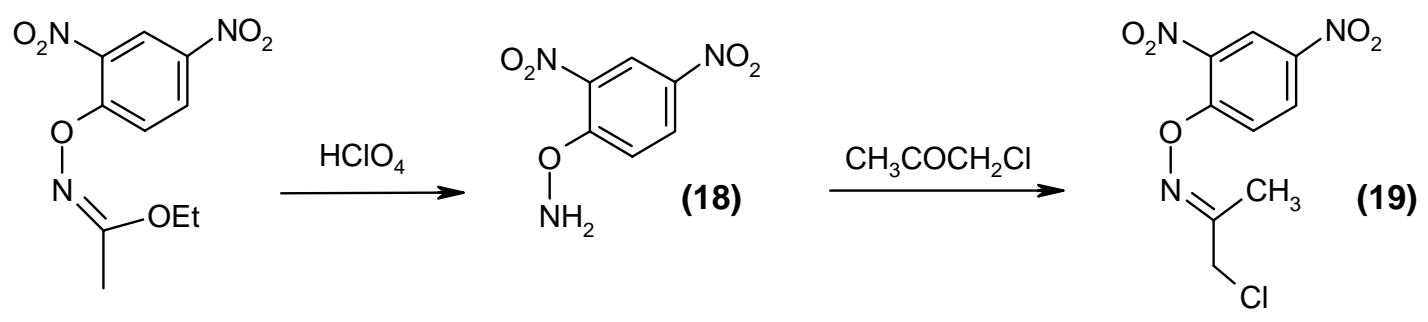

(17)
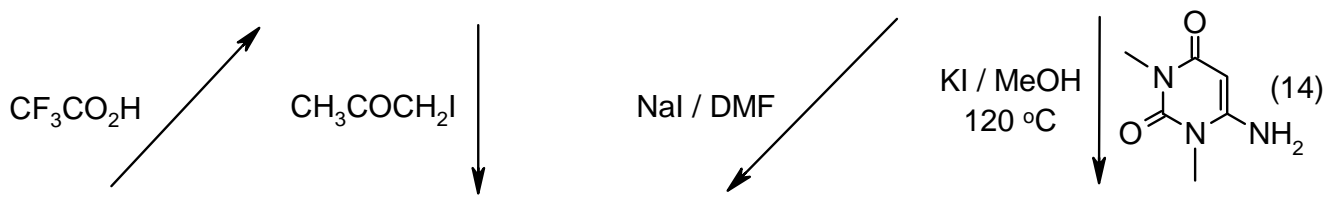<smiles>CC(C)(C)OC(=O)NOc1ccc([N+](=O)[O-])cc1[N+](=O)[O-]</smiles>

(20)

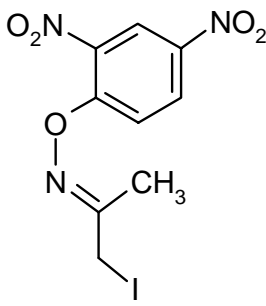

(21)

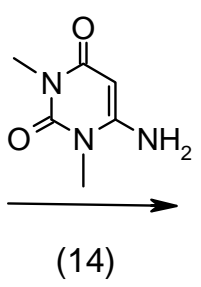

$(14)$<smiles>Cc1[nH]c2c(c1-c1cc([N+](=O)[O-])cc([N+](=O)[O-])c1O)c(=O)n(C)c(=O)n2C</smiles>

(22)

The proposed structure of the new product (22) rests on its spectral properties and microanalysis. Thus its high resolution mass spectrum showed a single peak at $\mathrm{m} / \mathrm{z} 376.0895$ $\left(\mathrm{M}+\mathrm{H}^{+}\right)$, indicating an empirical structure of $\mathrm{C}_{15} \mathrm{H}_{13} \mathrm{~N}_{5} \mathrm{O}_{7}$ for (22). This was confirmed by microanalysis. The ${ }^{1} \mathrm{H}$ NMR spectrum unexpectedly showed only two aromatic protons at $\delta 7.79$ and 8.65 and the appearance of these as two doublets with coupling constants of $J=3 \mathrm{~Hz}$, 
suggested two meta aromatic protons. The presence of a low field exchangeable signal $\left(\mathrm{D}_{2} \mathrm{O}\right)$ at $\delta 11.76$ was indicative of a phenolic $\mathrm{OH}$, and this was supported by an $\mathrm{OH}$ stretching band at $3401 \mathrm{~cm}^{-1}$ in the infrared spectrum. In agreement with the above, the ${ }^{13} \mathrm{C}$ NMR spectrum for (22) showed only two aromatic $\mathrm{CH}$ signals at $\delta 123.41$ and 128.83. Together, these results suggested the presence of a 2-hydroxy-3,5-dinitrophenyl moiety in the new molecule. The ${ }^{1} \mathrm{H}$ NMR spectrum also showed three methyl groups at $\delta 2.05,2.51$ and 3.14. Significantly, there was no signal attributable to a pyrimidine 5-H. Other important features in the NMR spectra were the exchangeable $\mathrm{NH}$ signal and the ten quaternary carbon signals. All of these data are in agreement with the proposed structure (22). These data are also consistent with the regioisomeric structure (23). This latter was ruled out, however, on the basis of NOE results, which showed a positive increase in intensity of the pyrrolo $\mathrm{CH}_{3}$ when the $\mathrm{NH}$ signal at $\delta 7.46$ was irradiated. Similarly, when the pyrrolo $\mathrm{CH}_{3}$ was irradiated, the $\mathrm{NH}$ signal increased in intensity. This shows that both these groups are in close proximity to each other in space, which result is compatible with structure (22), but not for the isomeric structure (23). Bennett and Mason ${ }^{14}$ prepared by a different route a compound similar to (22), which exists in the indolenine tautomeric form shown in (24). This was ascribed to steric interactions of the tertiary butyl group, however, and there is no reason to suppose that compound (22) should exist in its indolenine tautomeric form. Various other mechanisms for the reaction of (14) with (21) can be postulated. However, the products resulting from these can be ruled out on the basis of the spectroscopic data already described and the known reactivity of 6-amino-1,3-dimethyluracil (14). No analogous reaction was observed if 1,3-dimethyluracil or 6-methoxy-1,3-dimethyluracil were used instead of 6-amino-1,3dimethyluracil (14).

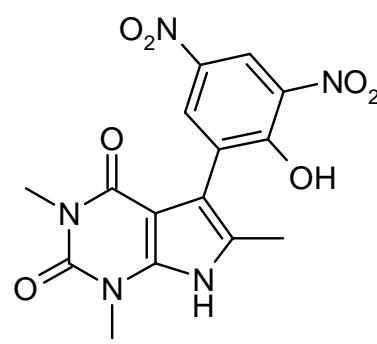

(22)

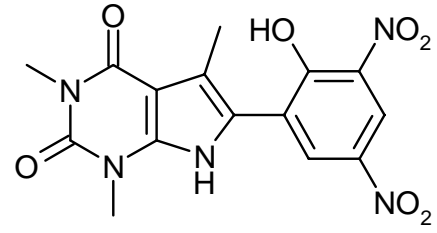

(23)

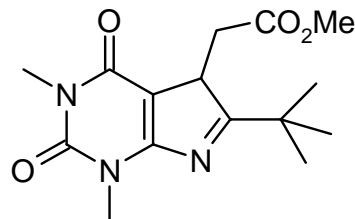

(24)

A suggested mechanism for the formation of (22) is shown below. The first step involves electrophilic substitution at the 5-position of (14), to give intermediate (25). A double bond shift leads to (26) and sets the system up for a [3,3] sigmatropic rearrangement in which (26) is converted into (27). This step is similar to both the Claisen allyl ether rearrangement and the key step in the Fischer indole synthesis. An intramolecular nucleophilic attack by nitrogen on the imine carbon centre in (27) leads to ring closure, giving the fused ring compound (28), which with loss of ammonia then gives the fully aromatic final product (22). Surprisingly, when the reaction was repeated using 1,3-dimethyl-6-methylaminouracil in place of the 6-amino compound (14), a dinitrobenzo[b] furan product (32) was obtained instead, and not the expected 
(29). The 1,3-dimethyl-6-methylaminouracil was prepared by treating 6-chloro-1,3dimethyluracil (7) with methylamine, using a modification of a method described by Pfleiderer. ${ }^{5}$ Again the structure of (32) follows from its properties. Significantly, the lack of a phenolic $\mathrm{OH}$ group signal in both its NMR and IR spectra indicated that the final cyclisation had followed a different route from that described already for the formation of (22). It is assumed that formation of (32) follows initially a pathway similar to that described for the formation of (22). The intermediate (30) formed by the sigmatropic rearrangement, however, now carries a substituted 6-amino group at the pyrimidine 6-position, and this appears to promote preferential intramolecular cyclisation on to the phenolic oxygen, leading to (31), which with loss of ammonia gives the fully aromatic benzo[b]furan product (32).<smiles>CCn1c(=O)c(/C=C(\C)NOc2ccc([N+](=O)[O-])cc2[N+](=O)[O-])c(N)n(C)c1=O</smiles><smiles>CC(=N)C(c1c(N)n(C)c(=O)n(C)c1=O)C1C=C([N+](=O)[O-])C=C([N+](=O)[O-])C1=O</smiles>

(27)<smiles>CCn1c2c(c(=O)n(C)c1=O)NC(C)(N)C2c1cc([N+](=O)[O-])cc([N+](=O)[O-])c1O</smiles>

(28)<smiles>CCn1c(=O)c2c(-c3cc([N+](=O)[O-])cc([N+](=O)[O-])c3O)c(C)[nH]c2n(C)c1=O</smiles>

(22)<smiles>Cc1c(-c2cc([N+](=O)[O-])cc([N+](=O)[O-])c2O)c2c(=O)n(C)c(=O)n(C)c2n1C</smiles>

(29)<smiles>CNc1c(C(C(C)=N)c2cc([N+](=O)[O-])cc([N+](=O)[O-])c2O)c(=O)n(C)c(=O)n1C</smiles>

(30)

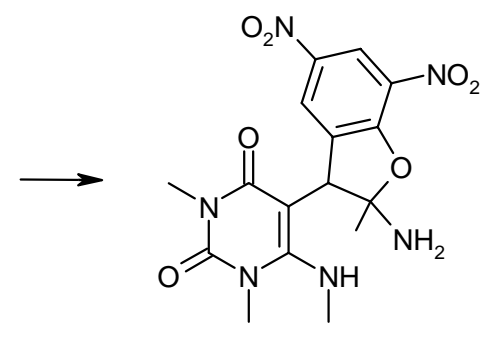

(31)

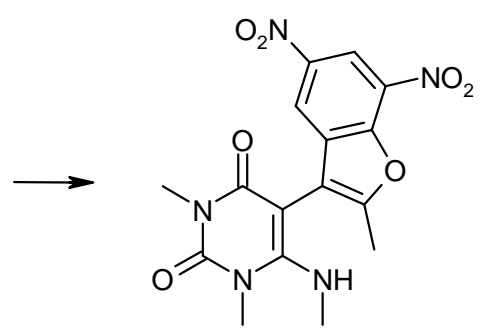

(32)

Yet another variation of this type of reaction was observed when 6-amino-2-phenyl-4(3H)pyrimidinone (33) was reacted with the chloro oxime (19), using the same experimental conditions as already described for the preparation of (22) and (32). This time a furo[2,3d]pyrimidine was obtained and was shown to have structure (35). Its high resolution mass spectrum showed a single peak at $\mathrm{m} / \mathrm{z} 408.0976\left(\mathrm{M}+\mathrm{H}^{+}\right)$, indicating an empirical formula for 
(35) of $\mathrm{C}_{19} \mathrm{H}_{13} \mathrm{~N}_{5} \mathrm{O}_{6}$. The ${ }^{1} \mathrm{H}$ NMR spectrum showed peaks at $\delta 8.14$ and 8.65 corresponding to a pair of meta aromatic protons. Peaks at $\delta 6.84$ and 12.06 showed the presence of an $\mathrm{NH}_{2}$ group and a phenolic $\mathrm{OH}$ group, respectively, while there was no peak that could have been attributed to a pyrimidine 5-H. The first step in the formation of (35) involves pyrimidine (33) reacting nucleophilically at its oxygen with the chloro oxime (19) to give (34). This latter is converted into (35) by a tautomeric double bond shift, followed by a [3,3] sigmatropic rearrangement, intramolecular cyclisation onto the nucleophilic pyrimidine 5-position, and final loss of ammonia. Other structures isomeric with (35) may be drawn which fit the spectroscopic data, for example structure (36). Formation of the latter would involve (33) reacting nucleophilically at its 5-position with the chloro oxime (19). It is known, however, that (33) reacts with chloroacetone at its exocyclic oxygen atom, ${ }^{15}$ and to our knowledge there are no examples of (33) reacting with halo compounds at the 6-amino group, or at the 5-position. It always seems to prefer reaction at the lactam oxygen. It is also possible to envisage several other routes by which (33) and (19) could react together, but in all cases they lead to products that would be incompatible with the observed spectroscopic data.<smiles>C/C(=N/Oc1ccc([N+](=O)[O-])cc1[N+](=O)[O-])Oc1cc(N)nc(-c2ccccc2)n1</smiles>

(34)

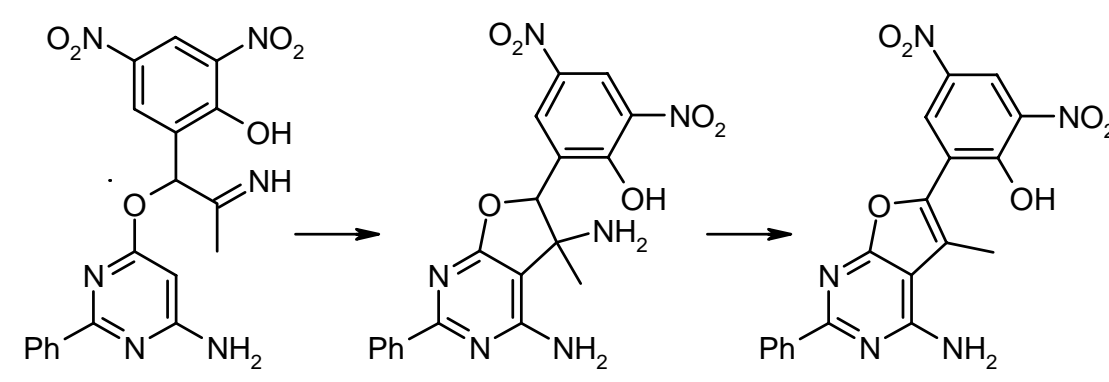

(35)

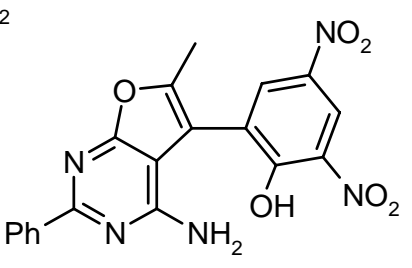

(36)

\section{Conclusions}

Many years ago Sheradsky reported a Fischer type reaction of O-phenyloximes to give benzofurans, ${ }^{16}$ and more recently Shudo and co-workers found that some aryl hydroxamates can rearrange under strongly acidic conditions. ${ }^{17}$ Rearrangements of this type are rare, however, and 
to our knowledge have not been observed before in 2,4-dinitrophenyl oximes. In summary, therefore, this present work has uncovered a [3,3] sigmatropic rearrangement of 2,4dinitrophenyl oximes, in which two of the six reacting atoms were nitrogen and oxygen. The initially formed product was found to undergo intramolecular cyclisation in a variety of ways leading to different ring systems, including a pyrrolo[2,3-d]pyrimidine (22), a benzo[b]furan (32) and a furo[2,3-d]pyrimidine (35).

\section{Experimental Section}

General Procedures. All reagents not prepared in the laboratory were purchased either from Aldrich Chemical Company or from Lancaster Synthesis Ltd. (UK). Thin layer chromatography (TLC) was carried out using Merck (silica gel 60) TLC aluminium sheets. Visualisation was achieved by the use of either UV light or by development over iodine adsorbed onto silica. Column chromatography was carried out using manually prepared columns containing 'flash' silica gel, which was packed under pressure. Elemental analysis was carried out in the microanalytical laboratory, Department of Chemistry, University College Dublin. Melting points are uncorrected and were measured on an Electrothermal 9100 heating ramp. NMR spectra were recorded on a Bruker DPX 400 instrument, operating at $400.14 \mathrm{MHz}$ for ${ }^{1} \mathrm{H}$ analysis and 100.14 $\mathrm{MHz}$ for ${ }^{13} \mathrm{C}$ analysis. Samples were referenced against tetramethylsilane (TMS). Chemical shifts are reported in ppm with coupling constants $(J)$ in hertz. Infrared spectra were recorded in the range $4000-600 \mathrm{~cm}^{-1}$ on a Perkin-Elmer 1600 series FTIR. Samples were run as $8 \mathrm{~mm}$ diameter potassium bromide pellets unless otherwise indicated. Electrospray mass spectroscopy was carried out using a Micromass $\mathrm{LCT}^{\circledR}$ in either positive or negative mode. Samples were dissolved in HPLC grade methanol at a concentration of $\sim 2 \mathrm{ng} / \mathrm{L}$ and analysed using a mobile phase of 50:50 methanol:water, unless otherwise stated. High resolution mass spectroscopy used an internal standard of leucine enkephalin (Aldrich). UV spectra were measured on a Varian Cary 300 UV-Vis spectrophotometer. HPLC was carried out using a Shimadzu HPLC system incorporating an SCL-10AVP system controller, a SPD-M10AVP PDA detector, a LC-10ADVP liquid chromatograph controller and a SIL-10ADVP Auto Injector. The mobile phase was water: $\mathrm{MeOH}, 85: 15$, and routine work was done using a Hichrome HD05S reverse phase column at a flow rate of $0.35 \mathrm{~mL} / \mathrm{min}$.

1,3-Dimethylpyrolo[2,3-d]pyrimidine-2,4(1H,3H)-dione (10). 6-(2,2-Diethoxy-ethylamino)1,3-dimethylpyrimidine-2,4(1H,3H)-dione (8) $(0.1 \mathrm{~g} ; 0.37 \mathrm{mmol})$ was dissolved in $1 \mathrm{M}$ aqueous $\mathrm{HCl}(10 \mathrm{ml})$ and stirred for three hours at room temperature. The resulting white precipitate was collected, washed with cold water, and dried over $\mathrm{P}_{2} \mathrm{O}_{5}$ overnight to give 1,3dimethylpyrrolo[2,3-d]pyrimidine-2,4(1H,3H)-dione ${ }^{7}$ (10) $\left(0.5\right.$ g; 78\%); m.p. $>250{ }^{\circ} \mathrm{C} ; \mathrm{R}_{\mathrm{f}}$ (DCM:MeOH, 9:1) 0.3; $\left.\lambda_{\max }(\mathrm{EtOH}) / \mathrm{nm}\right) 243$ and 275; $\delta_{\mathrm{H}}\left(400 \mathrm{MHz} ; \mathrm{CDCl}_{3}\right) 3.21\left(3 \mathrm{H}, \mathrm{s}, \mathrm{CH}_{3}\right)$, $3.43\left(3 \mathrm{H}, \mathrm{s}, \mathrm{CH}_{3}\right), 6.36(1 \mathrm{H}, \mathrm{d}, \mathrm{CH}), 6.77(1 \mathrm{H}, \mathrm{d}, \mathrm{CH})$ and $11.67(1 \mathrm{H}, \mathrm{s}, \mathrm{NH}) ; \delta_{\mathrm{C}}(100 \mathrm{MHz}$; 
$\left.\mathrm{CDCl}_{3}\right)+$ DEPT $27.59\left(\mathrm{CH}_{3}\right), 30.47\left(\mathrm{CH}_{3}\right), 98.52(\mathrm{Cq}), 103.84(\mathrm{CH}), 116.73(\mathrm{CH})$ and 138.86 $(\mathrm{Cq}), 150.80(\mathrm{Cq})$ and $158.50(\mathrm{Cq}) \cdot \mathrm{m} / \mathrm{z}(\mathrm{ESI}) 180.21\left(\mathrm{M}+\mathrm{H}^{+}\right)$.

6-(2-Hydroxypropylamino)-1,3-dimethyluracil (11). 1-Amino-2-propanol (13.2 $\mathrm{mL}$, $171.8 \mathrm{mmol})$ was added to a suspension of 6-chloro-1,3-dimethyluracil (7) $(3 \mathrm{~g}, 17.18 \mathrm{mmol})$ in water $(8 \mathrm{~mL})$ and the mixture was heated at $100{ }^{\circ} \mathrm{C}$ for 30 minutes. The solvent was removed under vacuum to give a yellow oil, which was purified by column chromatography $\left(\mathrm{CH}_{2} \mathrm{Cl}_{2}\right.$ :EtOH, 7:3). 6-(2-Hydroxypropylamino)-1,3-dimethyluracil (11) was obtained as a white solid, which was recrystallised from EtOH, (2.9 g; 79\%). $\mathrm{R}_{\mathrm{f}}\left(\mathrm{CH}_{2} \mathrm{Cl}_{2}\right.$ :EtOH, 7:3) 0.41; m.p. 132$134{ }^{\circ} \mathrm{C}$; (Found $\mathrm{C}, 50.56 ; \mathrm{H}, 7.01 ; \mathrm{N}, 19.62 ; \mathrm{C}_{9} \mathrm{H}_{15} \mathrm{~N}_{3} \mathrm{O}_{3}$ requires $\mathrm{C}, 50.69 ; \mathrm{H}, 7.09 ; \mathrm{N}, 19.71 \%$ ); $v_{\max }(\mathrm{KBr}) / \mathrm{cm}^{-1} 3426,3315,1683,1598,1548,1467,1429,1379,1340,1305,1240,1116 ; \lambda_{\max }$ $(\mathrm{MeOH}) / \mathrm{nm} 203$ and 267; $\delta_{\mathrm{H}}\left(400 \mathrm{MHz}\right.$; d 6 -DMSO) $1.08\left(3 \mathrm{H}, \mathrm{d}, \mathrm{CH}_{3}\right), 2.98\left(2 \mathrm{H}, \mathrm{m}, \mathrm{CH}_{2}\right), 3.09$ $\left(3 \mathrm{H}, \mathrm{s}, \mathrm{CH}_{3}\right), 3.30\left(3 \mathrm{H}, \mathrm{s}, \mathrm{CH}_{3}\right), 3.84(1 \mathrm{H}, \mathrm{m}, \mathrm{CH}), 4.72(1 \mathrm{H}, \mathrm{s}, \mathrm{CH}), 6.61(1 \mathrm{H}, \mathrm{br} \mathrm{s}, \mathrm{NH})$ and $7.23\left(1 \mathrm{H}\right.$, br s, OH); $\delta_{\mathrm{C}}\left(100 \mathrm{MHz} ; \mathrm{d}_{6}-\mathrm{DMSO}\right)+$ DEPT $20.98\left(\mathrm{CH}_{3}\right), 27.05\left(\mathrm{CH}_{3}\right), 50.01\left(\mathrm{CH}_{2}\right)$ $63.58(\mathrm{CH}), 73.50(\mathrm{CH})$ and 151.51, 153.67, $161.57(\mathrm{Cq}) ; \mathrm{m} / \mathrm{z}(\mathrm{ESI}) 214.23\left(\mathrm{M}+\mathrm{H}^{+}\right)$and 236.18 $\left(\mathrm{M}+\mathrm{Na}^{+}\right)$; Exact mass, Calcd. for $\mathrm{C}_{9} \mathrm{H}_{16} \mathrm{~N}_{3} \mathrm{O}_{3}\left(\mathrm{M}+\mathrm{H}^{+}\right)$: 214.1192. Found; 214.1190 .

6-(2-Hydroxy-2-phenylethylamino)-1.3-dimethyluracil. 6-Chloro-1,3-dimethyluracil (7) (1 g, $5.73 \mathrm{mmol})$ and 2-amino-1-phenylethanol $(1.57 \mathrm{~g}, 11.46 \mathrm{mmol})$ in ethanol $(20 \mathrm{ml})$ were heated to $50{ }^{\circ} \mathrm{C}$ to effect solution. Triethylamine $(0.8 \mathrm{~mL}, 5.73 \mathrm{mmol})$ was added and the reaction mixture was refluxed for $12 \mathrm{~h}$. The white precipitate that formed on cooling was collected and recrystallised from $\mathrm{EtOH}$ to give 6-(2-hydroxy-2-phenylethylamino)-1.3-dimethyluracil as a white crystalline solid (1.38 g; 87\%). $\mathrm{R}_{\mathrm{f}}\left(\mathrm{CH}_{2} \mathrm{Cl}_{2}: \mathrm{EtOH}, 9: 1\right)$ 0.48; m.p. 174-175 ${ }^{\circ} \mathrm{C}$; (Found C, $60.84 ; \mathrm{H}, 6.16 ; \mathrm{N}, 15.19 ; \mathrm{C}_{14} \mathrm{H}_{17} \mathrm{~N}_{3} \mathrm{O}_{3}$ requires $\left.\mathrm{C}, 61.08 ; \mathrm{H}, 6.22 ; \mathrm{N}, 15.26 \%\right) ; v_{\max }(\mathrm{KBr}) / \mathrm{cm}^{-1}$ 3342 , 3212, 1697, 1627, 1603, 1553, 1498, 1473, 1451, 1432, 1383, 1371, 1362, 1299, 1174 , 1059; $\lambda_{\max }(\mathrm{MeOH}) / \mathrm{nm} 208$ and 268; $\delta_{\mathrm{H}}\left(400 \mathrm{MHz} ; \mathrm{d}_{6}-\mathrm{DMSO}\right) 3.21\left(2 \mathrm{H}, \mathrm{d}, \mathrm{CH}_{2}\right), 3.28(3 \mathrm{H}, \mathrm{s}$, $\left.\mathrm{CH}_{3}\right), 3.36\left(3 \mathrm{H}, \mathrm{s}, \mathrm{CH}_{3}\right), 4.78(1 \mathrm{H}, \mathrm{m}, \mathrm{CH}), 5.63(1 \mathrm{H}, \mathrm{s}, \mathrm{CH}), 6.72(1 \mathrm{H}$, br s, NH), $7.35(5 \mathrm{H}, \mathrm{m}$, $\mathrm{CH}, \mathrm{Ph}.) ; \delta_{\mathrm{C}}\left(100 \mathrm{MHz} ; \mathrm{d}_{6}\right.$-DMSO) + DEPT $27.50\left(\mathrm{CH}_{3}\right), 29.59\left(\mathrm{CH}_{3}\right), 50.70\left(\mathrm{CH}_{2}\right), 69.96$ $(\mathrm{CH}), 74.16(\mathrm{CH}), 126.37(\mathrm{CH}), 127.63(\mathrm{CH}), 128.52(\mathrm{CH})$ and 143.07, 151.5, 153.22, 161.59 $(\mathrm{Cq}) ; \mathrm{m} / \mathrm{z}(\mathrm{ESI}) 258.15\left(\mathrm{M}-\mathrm{H}_{2} \mathrm{O}\right), 276.16\left(\mathrm{M}+\mathrm{H}^{+}\right)$and $298.14\left(\mathrm{M}+\mathrm{Na}^{+}\right)$; Exact mass, Calcd. for $\mathrm{C}_{14} \mathrm{H}_{17} \mathrm{~N}_{3} \mathrm{O}_{3}\left(\mathrm{M}+\mathrm{H}^{+}\right): 276.1348$. Found; 276.1352 .

6-(2-Oxopropylamino)-1,3-dimethyluracil (12) and 1,3,5-trimethylpyrrolo-[2,3-d]pyrimidine-2,4(1H,3H)-dione (13). Oxalyl chloride (488 $\mu \mathrm{L}, 5.61 \mathrm{mmol})$ was dissolved in dry $\mathrm{CH}_{2} \mathrm{Cl}_{2}(7 \mathrm{~mL})$ at $-60{ }^{\circ} \mathrm{C}$ (acetone/ solid $\mathrm{CO}_{2}$ bath) under $\mathrm{N}_{2}$. To this, a dry $\mathrm{CH}_{2} \mathrm{Cl}_{2}$ solution $(7 \mathrm{~mL})$ of DMSO $(639 \mu \mathrm{L} ; 11.2 \mathrm{mmol})$ was added dropwise over $10 \mathrm{~min}$. 6-(2Hydroxypropylamino)-1,3-dimethyluracil (11) (1 g, $4.65 \mathrm{mmol}$ ) was dissolved in dry $\mathrm{CH}_{2} \mathrm{Cl}_{2}$ $(40 \mathrm{~mL})$ under $\mathrm{N}_{2}$ and the solution was added slowly to the reaction mixture, maintaining a temperature of $-55^{\circ} \mathrm{C}$. The reaction solution was stirred for $30 \mathrm{~min}$. at which time it was quenched by the addition of triethylamine $(3.3 \mathrm{~mL} ; 23.5 \mathrm{mmol})$. A crude yellow solid was isolated from the reaction solution, which after column chromatography (silica; $\mathrm{CH}_{2} \mathrm{Cl}_{2}: \mathrm{EtOH}$, 9:1-8:2) gave 6-(2-oxopropylamino)-1,3-dimethyluracil (12) as a cream coloured solid (0.106 g; 10.7\%). $\mathrm{R}_{\mathrm{f}}\left(\mathrm{CH}_{2} \mathrm{Cl}_{2}: \mathrm{EtOH}, 9: 1\right)$ 0.48; $\delta_{\mathrm{H}}\left(400 \mathrm{MHz} ; \mathrm{CDCl}_{3}\right) 2.33\left(3 \mathrm{H}, \mathrm{s}, \mathrm{CH}_{3}\right), 3.31\left(3 \mathrm{H}, \mathrm{s}, \mathrm{CH}_{3}\right)$, 
$3.47\left(3 \mathrm{H}, \mathrm{s}, \mathrm{CH}_{3}\right), 3.97\left(2 \mathrm{H}, \mathrm{d}, \mathrm{CH}_{3}\right), 5.30(1 \mathrm{H}, \mathrm{s}, \mathrm{CH}), 4.48\left(1 \mathrm{H}\right.$, br s, NH); $\delta_{\mathrm{C}}(100 \mathrm{MHz}$; $\left.\mathrm{CDCl}_{3}\right)+$ DEPT $27.26\left(\mathrm{CH}_{3}\right), 27.70\left(\mathrm{CH}_{3}\right), 28.42\left(\mathrm{CH}_{3}\right), 52.19\left(\mathrm{CH}_{2}\right), 76.27(\mathrm{CH})$ and 151.13, 153.45, 162.39, $200.36(\mathrm{Cq}) ; \mathrm{m} / \mathrm{z}$ (ESI) $212.12\left(\mathrm{M}+\mathrm{H}^{+}\right)$; Exact mass, Calcd. for $\mathrm{C}_{9} \mathrm{H}_{14} \mathrm{~N}_{3} \mathrm{O}_{3}$ $\left(\mathrm{M}+\mathrm{H}^{+}\right)$: 212.2285. Found; 212.2281. Also obtained from the column was 1,3,5trimethylpyrrolo[2,3-d]pyrimidine-2,4(1H,3H)-dione (13), which was recrystallised from EtOH to give white crystals $(0.63 \mathrm{~g} ; 70 \%) . \mathrm{R}_{\mathrm{f}}\left(\mathrm{CH}_{2} \mathrm{Cl}_{2}: \mathrm{EtOH}, 9: 1\right) 0.68 ;$ m.p. $>250{ }^{\circ} \mathrm{C} ; v_{\max }(\mathrm{KBr}) / \mathrm{cm}^{-}$

${ }^{1} 3154,1688,1623,1548,1436 ; \delta_{\mathrm{H}}\left(400 \mathrm{MHz} ; \mathrm{CDCl}_{3}\right) 2.28\left(3 \mathrm{H}, \mathrm{s}, \mathrm{CH}_{3}\right), 3.35\left(3 \mathrm{H}, \mathrm{s}, \mathrm{CH}_{3}\right), 3.50$ $\left(3 \mathrm{H}, \mathrm{s}, \mathrm{CH}_{3}\right), 5.89(1 \mathrm{H}, \mathrm{br} \mathrm{s}, \mathrm{NH})$ and $6.13(1 \mathrm{H}, \mathrm{s}, \mathrm{CH}) ; \delta_{\mathrm{C}}\left(100 \mathrm{MHz} ; \mathrm{CDCl}_{3}\right)+$ DEPT 10.87 $\left(\mathrm{CH}_{3}\right), 26.56\left(\mathrm{CH}_{3}\right), 29.07\left(\mathrm{CH}_{3}\right), 98.28(\mathrm{Cq}), 99.99(\mathrm{CH})$ and 127.23, 151.10, 159.60, 160.32 $(\mathrm{Cq}) ; \mathrm{m} / \mathrm{z}(\mathrm{ESI}) 194.21\left(\mathrm{M}+\mathrm{H}^{+}\right)$and $216.24\left(\mathrm{M}+\mathrm{Na}^{+}\right)$; Exact mass, Calcd. for $\mathrm{C}_{9} \mathrm{H}_{12} \mathrm{~N}_{3} \mathrm{O}_{2}$ $\left(\mathrm{M}+\mathrm{H}^{+}\right):$194.2133. Found; 194.2131.

6-Methoxy-1,3-dimethyluracil (15) and 1,3,5-trimethylpyrrolo[2,3-d]pyrimidine-2,4(1H,3H)dione (13). 6-Amino-1,3-dimethyluracil (14) (1 g, $6.4 \mathrm{mmol})$ was suspended in HPLC grade methanol $(10 \mathrm{~mL})$ in a pressure tube. To this was added iodoacetone $(512 \mu \mathrm{L}, 6.4 \mathrm{mmol})$, the tube was sealed and the suspension was heated overnight at $120^{\circ} \mathrm{C}$. After cooling, the resulting precipitate was collected and purified by column chromatography to give 6-methoxy-1,3dimethyluracil $^{18}$ (15) which was recrystallised from $\mathrm{MeOH}$ to give a crystalline solid $(0.21 \mathrm{~g}$; 38.5\%). $\mathrm{R}_{\mathrm{f}}\left(\mathrm{CH}_{2} \mathrm{Cl}_{2}: \mathrm{MeOH}, 9: 1\right)$ 0.72; m.p. $165^{\circ} \mathrm{C} ; \delta_{\mathrm{H}}\left(400 \mathrm{MHz} ; \mathrm{CDCl}_{3}\right) 3.30\left(3 \mathrm{H}, \mathrm{s}, \mathrm{CH}_{3}\right)$, $3.33\left(3 \mathrm{H}, \mathrm{s}, \mathrm{CH}_{3}\right), 3.87\left(3 \mathrm{H}, \mathrm{s}, \mathrm{CH}_{3}\right)$ and $5.11(1 \mathrm{H}, \mathrm{s}, \mathrm{CH}) ; \delta_{\mathrm{C}}\left(100 \mathrm{MHz} ; \mathrm{CDCl}_{3}\right)+$ DEPT 27.35 $\left(\mathrm{CH}_{3}\right), 28.25\left(\mathrm{CH}_{3}\right), 56.39\left(\mathrm{CH}_{3}\right), 77.21(\mathrm{CH}, \mathrm{C}-5)$ and 150.90, 160.88, $163.54(\mathrm{Cq}) ; \mathrm{m} / \mathrm{z}(\mathrm{ESI})$ $171.1\left(\mathrm{M}+\mathrm{H}^{+}\right)$and $193.1\left(\mathrm{M}+\mathrm{Na}^{+}\right)$; Exact mass, Calcd. for $\mathrm{C}_{7} \mathrm{H}_{10} \mathrm{~N}_{2} \mathrm{O}_{3}\left(\mathrm{M}+\mathrm{H}^{+}\right)$: 171.1760 . Found; 171.1758. Also obtained from the column was 1,3,5-trimethylpyrrolo[2,3-d]pyrimidine$2,4(1 H, 3 H)$-dione (13) $(0.34 \mathrm{~g} ; 40 \%)$, identical in all its properties with that prepared as described above.

1,3-Dimethyl-6-methoxyuracil (15). Sodium (0.05 g; $2.2 \mathrm{mmol})$ was dissolved in $\mathrm{MeOH}$ $(15 \mathrm{ml})$ and to the solution was added 6-chloro-1,3-dimethyluracil (7) $(0.2 \mathrm{~g} ; 1.1 \mathrm{mmol})$. The reaction mixture was refluxed for $2 \mathrm{~h}$. Removal of solvent under vacuum gave a salt, which was dissolved in water and the solution neutralised to $\mathrm{pH} 7$ with aqueous $\mathrm{HCl}$ and extracted with ethyl acetate. Cooling of the organic phase to $-4{ }^{\circ} \mathrm{C}$ gave 1,3 -dimethyl-6-methoxyuracil ${ }^{18}$ (15) as a white fluffy solid $(0.18 \mathrm{~g} ; 74 \%)$, identical in all its properties with that prepared as described above.

Ethyl $\boldsymbol{O}$-(2,4-dinitrophenyl)acetohydroxamate (17). Ethyl acetohydroxamate (2.02 g, $19.6 \mathrm{mmol}$ ) was dissolved in EtOH:water (20:1), containing $\mathrm{KOH}$ (1.32 g, $23.54 \mathrm{mmol})$. The solution was cooled to $-5^{\circ} \mathrm{C}$ and a solution of 2,4-dinitrochlorobenzene (4 g; $\left.19.76 \mathrm{mmol}\right)$ in $\mathrm{EtOH}(60 \mathrm{~mL})$ was added slowly, keeping the reaction temperature at or below $-5^{\circ} \mathrm{C}$. Once the addition was complete the reaction was stirred for $45 \mathrm{~min}$. and filtered to give a yellow solid, which on recrystallisation from EtOH yielded ethyl O-(2,4-dinitrophenyl)acetohydroxamate ${ }^{19}$ (17) as a cream coloured solid (4.56 g; 87\%); $\mathrm{R}_{\mathrm{f}}$ (DCM, 100\%) 0.93; m.p. 111-112 ${ }^{\circ} \mathrm{C}$; $\delta_{\mathrm{H}}(400$ $\left.\mathrm{MHz} ; \mathrm{CDCl}_{3}\right) 1.43\left(3 \mathrm{H}, \mathrm{t}, \mathrm{CH}_{3}\right), 2.27\left(3 \mathrm{H}, \mathrm{s}, \mathrm{CH}_{3}\right), 4.25\left(2 \mathrm{H}, \mathrm{q}, \mathrm{CH}_{2}\right), 7.90(1 \mathrm{H}, \mathrm{d}, \mathrm{CH}, J=9)$, $8.43(1 \mathrm{H}, \mathrm{dd}, \mathrm{CH}, J=7), 8.9(1 \mathrm{H}, \mathrm{d}, \mathrm{CH}, J=2.5) ; \delta_{\mathrm{C}}\left(100 \mathrm{MHz} ; \mathrm{CDCl}_{3}\right)+$ DEPT $13.74\left(\mathrm{CH}_{3}\right)$, 
$14.79\left(\mathrm{CH}_{3}\right), 63.49\left(\mathrm{CH}_{2}\right), 116.22(\mathrm{CH}), 121.63(\mathrm{CH}), 128.92(\mathrm{CH})$ and 136.21, 139.75, 157.26, $169.154(\mathrm{Cq})$.

O-(2,4-Dinitrophenyl)hydroxylamine (18). Ethyl O-(2,4-Dinitrophenyl)acetohydroxamate (17) $(0.5 \mathrm{~g}, 1.86 \mathrm{mmol})$ was dissolved in 1,4-dioxane $(2.5 \mathrm{~mL})$ at room temperature with stirring. To the yellow solution perchloric acid (70\%) $(1 \mathrm{~mL})$ was added dropwise. The solution was stirred at room temperature for $30 \mathrm{~min}$. and then added to ice $(15 \mathrm{~g})$ with vigorous agitation. The resulting yellow solid was collected, washed with EtOH, and dried to give O-(2,4dinitrophenyl)hydroxylamine ${ }^{12}$ (18) $(0.3 \mathrm{~g}, 82 \%)$. $\mathrm{R}_{\mathrm{f}}(\mathrm{DCM} ; 100 \%)$ 0.57; m.p. $113{ }^{\circ} \mathrm{C} ; v_{\max }$ $(\mathrm{KBr}) / \mathrm{cm}^{-1} 3327,3249,1606,1518$ and $1343 ; \delta_{\mathrm{H}}\left(400 \mathrm{MHz} ; \mathrm{CDCl}_{3}\right) 6.42\left(2 \mathrm{H}, \mathrm{br} \mathrm{s}, \mathrm{NH}_{2}\right), 8.07$ $(1 \mathrm{H}, \mathrm{d}, \mathrm{CH}, J=9.5), 8.45(1 \mathrm{H}, \mathrm{dd}, \mathrm{CH}, J=7.5), 8.82(1 \mathrm{H}, \mathrm{d}, \mathrm{CH}, J=2.5) ; \delta_{\mathrm{C}}\left(100 \mathrm{MHz} ; \mathrm{CDCl}_{3}\right)$ + DEPT $115.91(\mathrm{CH}), 121.43(\mathrm{CH}), 128.81(\mathrm{CH})$ and 140.23, 146.34, $159.10(\mathrm{Cq})$.

O-(2,4-Dinitrophenyl) oxime of chloroacetone (19). A solution of chloroacetone $(322 \mu \mathrm{L}, 5$ $\mathrm{mmol})$ in EtOH $(2 \mathrm{~mL})$ was added dropwise with stirring over $10 \mathrm{~min}$ to a solution of O-(2,4dinitrophenyl)hydroxylamine (18) $(1 \mathrm{~g}, 5 \mathrm{mmol})$ in trifluoroacetic acid $(15 \mathrm{~mL})$. The dark yellow solution was stirred for $30 \mathrm{~min}$. at room temperature, after which it was added slowly to ice (30 g), with vigorous agitation, to give the O-(2,4-dinitrophenyl) oxime of chloroacetone (19) as a yellow precipitate, which was collected, washed with water, dried and recrystallised from EtOH at $-4{ }^{\circ} \mathrm{C}$ overnight, (0.89 g; 65\%). $\mathrm{R}_{\mathrm{f}}\left(\mathrm{CH}_{2} \mathrm{Cl}_{2}, 100 \%\right.$ ) 0.73; m.p. 93-95 ${ }^{\circ} \mathrm{C}$; (Found $\mathrm{C}$, $39.23 ; \mathrm{H}, 2.77 ; \mathrm{N}, 15.16 ; \mathrm{C}_{9} \mathrm{H}_{8} \mathrm{ClN}_{3} \mathrm{O}_{5}$ requires $\left.\mathrm{C}, 39.51 ; \mathrm{H}, 2.95 ; \mathrm{N}, 15.36 \%\right) ; v_{\max }(\mathrm{KBr}) / \mathrm{cm}^{-1}$ $3099,1602,1525,1471,1340,1303,1264,1234,1142,1130,1067 ; \lambda_{\max }(\mathrm{MeOH}) / \mathrm{nm} 212$ and $271 ; \delta_{\mathrm{H}}\left(400 \mathrm{MHz} ; \mathrm{CDCl}_{3}\right) 2.35\left(3 \mathrm{H}, \mathrm{s}, \mathrm{CH}_{3}\right), 4.27\left(2 \mathrm{H}, \mathrm{s}, \mathrm{CH}_{2}\right) ; 7.94(1 \mathrm{H}, \mathrm{d}, \mathrm{CH}, J=9.5), 8.45$ $(1 \mathrm{H}, \mathrm{dd}, \mathrm{CH}, J=7), 8.88(1 \mathrm{H}, \mathrm{d}, \mathrm{CH}, J=2.5) ; \delta_{\mathrm{C}}\left(100 \mathrm{MHz} ; \mathrm{CDCl}_{3}\right)+\mathrm{DEPT} 13.90\left(\mathrm{CH}_{3}\right)$, $43.67\left(\mathrm{CH}_{2}\right), 116.80(\mathrm{CH}), 121.57(\mathrm{CH}), 128.85(\mathrm{CH})$ and 140.78, 154.23, 156.19, $162.11(\mathrm{Cq})$.

5-(2-Hydroxy-3,5-dinitrophenyl)-1,3,6-trimethylpyrrolo[2,3-d]pyrimidine-2,4(1H,3H)-dione (22). 6-Amino-1,3-dimethyluracil (14) (0.12 g; $0.78 \mathrm{mmol})$ was suspended in $\mathrm{MeOH}(5 \mathrm{~mL})$ in a pressure tube. To this was added the O-(2,4-dinitro-phenyl) oxime (19) of chloroacetone $(0.22 \mathrm{~g}$; $0.78 \mathrm{mmol})$ and $\mathrm{KI}(0.13 \mathrm{~g} ; 0.78 \mathrm{mmol})$ as a methanol $(5 \mathrm{~mL})$ suspension. The tube was sealed and heated at $120{ }^{\circ} \mathrm{C}$ overnight. On cooling, the resulting dark orange precipitate was collected, washed with $\mathrm{MeOH}$ and dried. Purification by column chromatography $\left(\mathrm{CH}_{2} \mathrm{Cl}_{2}\right.$ :EtOH, 9:1 EtOH 100\%) yielded 5-(2-hydroxy-3,5-dinitrophenyl)-1,3,6-trimethylpyrrolo[2,3-d]pyrimidine2,4(1H,3H)-dione (22) (0.16 g; 56\%). $\mathrm{R}_{\mathrm{f}}\left(\mathrm{CH}_{2} \mathrm{Cl}_{2}: \mathrm{EtOH}, 9: 1\right)$ 0.57; m.p. > $250{ }^{\circ} \mathrm{C}$; (Found C, $50.56 ; \mathrm{H}, 7.01 ; \mathrm{N}, 19.62 ; \mathrm{C}_{9} \mathrm{H}_{15} \mathrm{~N}_{3} \mathrm{O}_{3}$ requires $\left.\mathrm{C}, 50.69 ; \mathrm{H}, 7.09 ; \mathrm{N}, 19.71 \%\right) ; v_{\max }(\mathrm{KBr}) / \mathrm{cm}^{-1}$ 3401, 3132, 3046, 2948, 1684, 1635, 1541, 1499, 1386, 1335, 1249, 1233, 1158, 1098, 1055 ; $\lambda_{\max }(\mathrm{MeOH}) / \mathrm{nm} 204,266$ and 376; $\delta_{\mathrm{H}}\left(400 \mathrm{MHz}\right.$; d -DMSO $2.05\left(3 \mathrm{H}, \mathrm{s}, \mathrm{CH}_{3}\right), 2.51(3 \mathrm{H}, \mathrm{s}$, $\left.\mathrm{CH}_{3}\right), 3.14\left(3 \mathrm{H}, \mathrm{s}, \mathrm{CH}_{3}\right), 7.46(1 \mathrm{H}, \mathrm{br} \mathrm{s}, \mathrm{NH}), 7.79(1 \mathrm{H}, \mathrm{d}, \mathrm{CH}, J=3), 8.65(1 \mathrm{H}, \mathrm{d}, \mathrm{CH}, J=3)$ and $11.76\left(1 \mathrm{H}\right.$, br s, OH); $\delta_{\mathrm{C}}\left(100 \mathrm{MHz} ; \mathrm{d}_{6}-\mathrm{DMSO}\right)+$ DEPT $11.71\left(\mathrm{CH}_{3}\right), 27.42\left(\mathrm{CH}_{3}\right), 30.43$ $\left(\mathrm{CH}_{3}\right), 97.24(\mathrm{Cq}), 112.83(\mathrm{Cq}), 123.41(\mathrm{CH}), 125.05(\mathrm{Cq}), 126.99(\mathrm{Cq}), 128.83(\mathrm{CH})$ and 130.33, 136.27, 137.98, 150.58, 157.86, $168.59(\mathrm{Cq}) ; \mathrm{m} / \mathrm{z}(\mathrm{ESI}) 376.12\left(\mathrm{M}+\mathrm{H}^{+}\right)$; Exact mass, Calcd. for $\mathrm{C}_{15} \mathrm{H}_{14} \mathrm{~N}_{5} \mathrm{O}_{7}\left(\mathrm{M}+\mathrm{H}^{+}\right)$: 376.0893 . Found; 376.0895 . 
1,3-Dimethyl-6-methylaminouracil. Aqueous methylamine $(2.25 \mathrm{~mL} ; 40 \% \mathrm{w} / \mathrm{v})$ was added to a suspension of 6-chloro-1,3-dimethyluracil (7) (1 g, $5.73 \mathrm{mmol})$ in water $(20 \mathrm{~mL})$. The suspension was refluxed for $1 \mathrm{~h}$, after which most of the water was removed under vacuum. The white precipitate which formed on cooling was collected, washed with water, and recrystallised from EtOH to give 1,3-dimethyl-6-methylaminouracil ${ }^{5}$ as a white fluffy solid $(0.73 \mathrm{~g} ; 75 \%)$; $\mathrm{R}_{\mathrm{f}}$ $\left(\mathrm{CH}_{2} \mathrm{Cl}_{2}: \mathrm{EtOH}, 9: 1\right)$ 0.38; m.p. $245-246{ }^{\circ} \mathrm{C} ; \delta_{\mathrm{H}}\left(400 \mathrm{MHz} ; \mathrm{CDCl}_{3}\right) 2.86\left(3 \mathrm{H}, \mathrm{d}, \mathrm{CH}_{3}\right), 3.33(3 \mathrm{H}$, $\left.\mathrm{s}, \mathrm{CH}_{3}\right), 4.75\left(3 \mathrm{H}, \mathrm{s}, \mathrm{CH}_{3}\right), 4.75\left(1 \mathrm{H}\right.$, br s, NH), $4.85(1 \mathrm{H}, \mathrm{s}, \mathrm{CH}) ; \delta_{\mathrm{C}}\left(100 \mathrm{MHz} ; \mathrm{CDCl}_{3}\right)+\mathrm{DEPT}$ $27.29\left(\mathrm{CH}_{3}\right), 28.01\left(\mathrm{CH}_{3}\right), 29.37\left(\mathrm{CH}_{3}\right), 74.78(\mathrm{CH})$ and 151.24, 153.46, $161.24(\mathrm{Cq}) ; \mathrm{m} / \mathrm{z}(\mathrm{ESI})$ $170.24\left(\mathrm{M}+\mathrm{H}^{+}\right)$.

\section{1,3-Dimethyl-6-methylamino-5-(2-methyl-5,7-dinitro-3-benzo[b]furanyl)pyrimidine-}

2,4(1H,3H)-dione (32). 1,3-Dimethyl-6-methylaminouracil (120 mg, $0.73 \mathrm{mmol}$ ) was suspended in $\mathrm{MeOH}(5 \mathrm{~mL})$ contained in a pressure tube. To this was added the $\mathrm{O}-(2,4$-dinitrophenyl) oxime (19) of chloroacetone $(200 \mathrm{mg}, 0.73 \mathrm{mmol})$ and a suspension of $\mathrm{KI}(120 \mathrm{mg}, 0.73 \mathrm{mmol})$ in methanol $(5 \mathrm{~mL})$. The tube was sealed and allowed to heat at $120{ }^{\circ} \mathrm{C}$ overnight. The resulting dark orange precipitate was collected, washed with $\mathrm{MeOH}$ and dried to give 1,3-dimethyl-6methylamino-5-(2-methyl-5,7-dinitro-3-benzo[b]furanyl)pyrimidine-2,4(1H,3H)-dione (0.14 g; 49\%); $\mathrm{R}_{\mathrm{f}}\left(\mathrm{CH}_{2} \mathrm{Cl}_{2}: \mathrm{EtOH}, 9: 1\right)$ 0.48; m.p. > $250{ }^{\circ} \mathrm{C} ; v_{\max }(\mathrm{KBr}) / \mathrm{cm}^{-1} 3102,1686,1615$, $1561,1534,1458,1385,1315,1265,1174,1100 ; \lambda_{\max }(\mathrm{MeOH}) / \mathrm{nm} \mathrm{219,} 286$ and 375; $\delta_{\mathrm{H}}(400$ MHz; d 6 -DMSO, $2.09\left(3 \mathrm{H}, \mathrm{s}, \mathrm{CH}_{3}\right), 3.17\left(3 \mathrm{H}, \mathrm{d}, \mathrm{CH}_{3}\right), 3.78\left(3 \mathrm{H}, \mathrm{s}, \mathrm{CH}_{3}\right), 3.85\left(3 \mathrm{H}, \mathrm{s}, \mathrm{CH}_{3}\right)$, $8.16(1 \mathrm{H}, \mathrm{d}, \mathrm{CH}, J=3)$ and $8.72(1 \mathrm{H}, \mathrm{d}, \mathrm{CH}, J=3) ; \delta_{\mathrm{C}}\left(100 \mathrm{MHz} ; \mathrm{d}_{6}-\mathrm{DMSO}\right)+$ DEPT 10.75 $\left(\mathrm{CH}_{3}\right), 27.96\left(\mathrm{CH}_{3}\right), 32.52\left(\mathrm{CH}_{3}\right), 33.13\left(\mathrm{CH}_{3}\right), 98.26(\mathrm{Cq}), 108.65(\mathrm{Cq}), 120.11(\mathrm{CH}), 127.67$ $(\mathrm{Cq}), 128.87(\mathrm{Cq}), 131.34(\mathrm{CH})$ and 136.57, 137.53, 138.73, 151.39, 155.796, 157.55, 178.71 $(\mathrm{Cq}) ; \mathrm{m} / \mathrm{z}(\mathrm{ESI}) 390.52\left(\mathrm{M}+\mathrm{H}^{+}\right), 412.09\left(\mathrm{M}+\mathrm{Na}^{+}\right)$and $801.20\left(\mathrm{M}_{2}+\mathrm{H}^{+}\right)$; Exact mass, Calcd. for $\mathrm{C}_{16} \mathrm{H}_{16} \mathrm{~N}_{5} \mathrm{O}_{7}\left(\mathrm{M}+\mathrm{H}^{+}\right): 390.1050$. Found; 390.1067 .

4-Amino-6-(2-hydroxy-3,5-dinitrophenyl)-5-methyl-2-phenylfuro[2,3-d]pyrimidine (35). 6Amino-2-phenyl-4(3H)-pyrimidinone (33) $(0.11 \mathrm{~g}, 0.58 \mathrm{mmol})$ was suspended in $\mathrm{MeOH}(6 \mathrm{~mL})$ in a pressure tube. To this was added the O-(2,4-dinitrophenyl) oxime (19) of chloroacetone $(0.16 \mathrm{~g}, 0.58 \mathrm{mmol})$ and $\mathrm{KI}(0.10 \mathrm{~g}, 0.58 \mathrm{mmol})$ as a suspension in methanol $(5 \mathrm{~mL})$. The tube was sealed and kept at $120{ }^{\circ} \mathrm{C}$ overnight. The resulting dark brown precipitate was collected and purified by column chromatography $\left(\mathrm{CH}_{2} \mathrm{Cl}_{2}: \mathrm{MeOH}, 8.5: 1.5\right)$ to give 4-amino-6-(2-hydroxy-3,5dinitrophenyl)-5-methyl-2-phenylfuro[2,3-d]pyrimidine (35) as an orange solid (0.08 g; 36\%); $\mathrm{R}_{\mathrm{f}}$ $\left(\mathrm{CH}_{2} \mathrm{Cl}_{2}\right.$ :EtOH, 9:1) 0.39; m.p. 184-186 ${ }^{\circ} \mathrm{C} ; \delta_{\mathrm{H}}\left(400 \mathrm{MHz} ; \mathrm{d}_{6}-\mathrm{DMSO}\right.$,) $3.17\left(3 \mathrm{H}, \mathrm{s}, \mathrm{CH}_{3}\right), 6.84$ $\left(2 \mathrm{H}\right.$, br s, $\left.\mathrm{NH}_{2}\right), 7.53(2 \mathrm{H}, \mathrm{m}, \mathrm{Ph}), 8.11\left(3 \mathrm{H}, \mathrm{s}, \mathrm{CH}_{3}\right), 8.14(1 \mathrm{H}, \mathrm{d}, \mathrm{CH}, J=3)$ and $8.65(1 \mathrm{H}, \mathrm{d}$, $\mathrm{CH}, J=3)$ and $12.06(1 \mathrm{H}$, br s, OH $) ; \delta_{\mathrm{C}}\left(100 \mathrm{MHz}\right.$; $\left.\mathrm{d}_{6}-\mathrm{DMSO}\right)+\mathrm{DEPT} 30.61\left(\mathrm{CH}_{3}\right), 104.92$ $(\mathrm{Cq}), 109.55(\mathrm{Cq}), 121.06(\mathrm{Cq}), 127.23(\mathrm{CH}), 128.55(\mathrm{CH}), 127.21(\mathrm{CH} ; \mathrm{Ph}), 128.6(\mathrm{CH} ; \mathrm{Ph})$ and 131.22, 132.91, 137.24, 147.94, 150.24, 159.01, $206.5(\mathrm{Cq}) ; \mathrm{m} / \mathrm{z}(\mathrm{ESI}) 408.21\left(\mathrm{M}+\mathrm{H}^{+}\right)$, $430.09\left(\mathrm{M}+\mathrm{Na}^{+}\right)$; Exact mass, Calcd. for $\mathrm{C}_{19} \mathrm{H}_{14} \mathrm{~N}_{5} \mathrm{O}_{6}\left(\mathrm{M}+\mathrm{H}^{+}\right)$: 408.0944 . Found; 408.0976. 


\section{Acknowledgements}

Support received for this work from Trinity College Dublin is gratefully acknowledged. We are indebted to Dr. John O'Brien for help with the NMR spectra.

\section{References}

1. Kusama, H.; Yamashita, Y.; Narasaka, K. Chemistry Letters 1995, 5.

2. Kusama, H.; Uchiyama, K.; Yamashita, Y.; Narasaka, K. Chemistry Letters 1995, 715.

3. Ono, A.; Uchiyama, K.; Hayashi, Y.; Narasaka, K. Chemistry Letters 1998, 437.

4. Uchiyama, K.; Hayashi, Y.; Narasaka, K. Synlett 1997, 445.

5. Pfleiderer, W.; Schündehütte, K.-H. Liebigs Ann. Chem. 1958, 612, 158.

6. Rybár, A.; Pfleiderer, W. Collect. Czech. Chem. Commun. 1987, 52, 2722.

7. Seela, F.; Kretschmer, U. J. Heterocycl. Chem. 1990, 27, 479.

8. Kim, K.S.; Song, Y.H.; Lee, B.H.; Hahn, C.S. J .Org. Chem. 1986, 51, 404.

9. Kawahara, N.; Nakajima, T.; Itoh, T.; Ogura, H. Chem. Pharm. Bull. 1985, 3, 4740.

10. Ishikawa, I.; Khachatrian, V.E.; Melik-Ohanjanian, R.G.; Kawahara, N.; Mizuno, Y.; Ogura, H. Chem. Pharm. Bull. 1992, 40, 846.

11. Scholl; Matthaiopoulus Chem. Ber. 1896, 29, 1558.

12. Tamura, Y.; Minamikawa, J.; Sumoto, K.; Fujii, S.; Ikeda, M. J. Org. Chem. 1973, 38, 1239.

13. Sheradsky, T. J. Heterocycl. Chem. 1967, 4, 413.

14. Bennett, G.B.; Mason, R.B. J. Org. Chem. 1977, 42, 1919.

15. Duff, T.D. University of Dublin, 2000.

16. Sheradsky, T. Tetrahedron Lett. 1966, 5225.

17. Endo, Y.; Namikawa, K.; Shudo, K. Tetrahedron Lett. 1986, 27, 4209.

18. Gogoi, M.: Sandhu, J.S.; Baruah, J.N. Indian J. Chem. Section B 1984, 23, 851.

19. Ilvespää.A.O.; Marxer, A. Helv. Chim. Acta 1963, 46, 2009. 